\title{
In situ Synchrotron X-ray Powder Diffraction Study of the Early Hydration of $\alpha$-tricalcium Phosphate/tricalcium Silicate Composite Bone Cement
}

\author{
Loreley Morejón-Alonso ${ }^{a *}$, Mariana Motisuke ${ }^{b}$,José Raúl Correa ${ }^{a}$, \\ Raúl García Carrodeguas ${ }^{c}$, Luis Alberto dos Santos ${ }^{d}$ \\ ${ }^{a}$ Departamento de Química General, Facultad de Química, Universidad de La Habana - UH, Cuba \\ ${ }^{b}$ Universidade Federal de São Paulo - UNIFESP, Campus São José dos Campos, \\ São José dos Campos, SP, Brazil \\ ${ }^{c}$ Laboratório de Avaliação e Desenvolvimento de Biomateriais do Nordeste, Universidade \\ Federal de Campina Grande - UFCG, Campina Grande, PB, Brazil \\ ${ }^{d}$ Departamento de Materiais, Escola de Engenharia, Universidade Federal do \\ Rio Grande do Sul-UFRGS, Porto Alegre, RS, Brazil
}

Received: June 11, 2014; Revised: January 11, 2015

\begin{abstract}
Bioactivity, osteogenicity and mechanical properties of $\alpha$-tricalcium phosphate $(\alpha$-TCP) based phosphates cements can be improved by adding tricalcium silicate $\left(\mathrm{C}_{3} \mathrm{~S}\right)$; however, the addition of $\mathrm{C}_{3} \mathrm{~S}$ delays the precipitation and growth of calcium deficient hydroxyapatite (CDHA). Thus, the aim of this work was the study of in situ setting reaction of $\alpha-\mathrm{TCP} / \mathrm{C}_{3} \mathrm{~S}$ composite bone cement under high energy X-ray generated by a synchrotron source within the first $72 \mathrm{~h}$. The results showed that the addition of $\mathrm{C}_{3} \mathrm{~S}$ induces the precipitation of nanosized CDHA at early times depending on the added content. Calculated crystallite sizes showed that the higher the content of $\mathrm{C}_{3} \mathrm{~S}$, the smaller the crystal size at the beginning of the precipitation. These results are different from those obtained by conventional XRD method, suggesting that the proposed technique is a powerful tool in determining the composition and extent of reaction of CPCs surfaces in real time.
\end{abstract}

Keywords: calcium phosphate cements, hydroxyapatite, tricalcium silicate, X-ray diffraction

\section{Introduction}

Calcium phosphates cements (CPCs) are an excellent choice for the repair, augmentation and regeneration of bone tissue due to their good biocompatibility, bioresorbability, osteoconductivity and osteotransductive; in situ handling and shaping abilities; injectability; self-setting ability in vivo, as well as drug carriers ${ }^{1-4}$.

Among the different formulations of CPCs, stands out for its importance that based on $\alpha$-tricalcium phosphate powder $\left[\alpha-\mathrm{Ca}_{3}\left(\mathrm{PO}_{4}\right)_{2} ; \alpha-\mathrm{TCP}\right]$ which sets in situ and forms a calcium deficient hydroxyapatite $\left[\mathrm{Ca}_{9}\left(\mathrm{HPO}_{4}\right)\left(\mathrm{PO}_{4}\right)_{5}(\mathrm{OH})\right.$; CDHA] that is chemically similar to the inorganic phase of bone tissue. Moreover, in order to improve biocompatibility and osteogenicity of $\alpha$-TCP-based phosphate cements $s^{5-7}$ and also enhance the mechanical properties of the final materials after a period of time, silicon compounds such as dicalcium silicate $\left[\mathrm{Ca}_{2} \mathrm{SiO}_{4} ;(\mathrm{C} 2 \mathrm{~S})\right]$, tricalcium silicate $\left[\mathrm{Ca}_{3} \mathrm{SiO}_{5} ;\left(\mathrm{C}_{3} \mathrm{~S}\right)\right]$ and silica can be added to the conventional formulations ${ }^{8-12}$. However, the addition of these compounds delays the apatite formation at early stages in a range of concentrations, producing materials with low mechanical properties.

Dissolution of $\alpha$-TCP particles, further nuclei and precipitation of entanglement of crystals of CDHA, are the main causes of the increment of mechanical properties of CPCs. Furthermore, setting times give us information

*e-mail: lmorejon@fq.uh.cu related to the initial rates of reaction but not the extent of the cement reaction ${ }^{13}$; therefore, the evolution of the hydrolysis at early stages could be followed by in situ X-ray diffraction (XRD) such as X-ray energy generated by a synchrotron source, which is a powerful tool in the Material Science and Engineering field had been poorly documented in the study of these kinds of reactions, and never employed in the case of $\alpha$-TCP-based phosphate cements ${ }^{14}$.

Thus, the aim of this work was to characterize the in situ early hydration of the $\alpha-\mathrm{TCP} / \mathrm{C}_{3} \mathrm{~S}$ composite bone cement through high energy $\mathrm{X}$-ray diffraction.

\section{Experimental}

\subsection{Cement preparation}

The $\alpha$-TCP powder was prepared by means of $\mathrm{CaHPO}_{4}$ (Dyne ${ }^{\circledR}$, Pharmaceutical Grade) and $\mathrm{CaCO}_{3}$ (Nuclear, PA) as raw materials in appropriate quantities as described in previous work ${ }^{11}$. After calcination and milling, the as obtained powder, consisted of $82 \% \alpha$-TCP and $18 \% \beta$-tricalcium phosphate ( $\beta$-TCP), was mixed with synthetized $\mathrm{C}_{3} \mathrm{~S}$ obtained by sol-gel route, in powder ratios of $0,5.0$ and 10.0 mass $\%{ }^{15-16}$. The samples were labeled as TCP, TCP-5A, and TCP-10A according to the content of $\mathrm{C}_{3} \mathrm{~S}$ added (Table 1). The letter $A$ from Allite, the mineral 
name of $\mathrm{C}_{3} \mathrm{~S}$, was used instead of $\mathrm{C}_{3} \mathrm{~S}$ formula in order to simplify the captions.

The liquid phase consisted of a buffer solution of $\mathrm{NaH}_{2} \mathrm{PO}_{4}$ and $\mathrm{Na}_{2} \mathrm{HPO}_{4}$ and the liquid-to-powder ratio (L/P) was dependent on the content of $\mathrm{C}_{3} \mathrm{~S}$ added; ranging 0.4 to $0.44 \mathrm{~mL} / \mathrm{g}$. Each powder sample was carefully weighed and mixed with the liquid phase in appropriate $\mathrm{L} / \mathrm{P}$, loaded into the synchrotron holder and aged at $36.5^{\circ} \mathrm{C}$ with controlled humidity for $24 \mathrm{~h}$.

\subsection{Phase characterization}

The XRD patterns were measured in situ at the XRD2 beam line of the Brazilian Synchrotron Light Laboratory (LNLS), Campinas, São Paulo. Incident X-ray energy was $8 \mathrm{KeV}$ and a double crystal monochromator of $\mathrm{Si}$ (111) was used to obtain a monochromatic radiation $(\lambda=1.54182 \AA)$. The beam was vertically focused by an Rh-coated silicon mirror and the size of the beam spot when focused at the sample position was $5 \mathrm{~mm}$ in the horizontal and $1 \mathrm{~mm}$ in the vertical.

The data was collected by a Cyberstar X1000 detector (NaI (Ti) scintillator). The diffractograms were continuously recorded up to $48 \mathrm{~h}$ of hydration with a step size of $0.02^{\circ}$ and

Table 1. Compositions of formulations of $\alpha-\mathrm{TCP} / \mathrm{C}_{3} \mathrm{~S}$ composite.

\begin{tabular}{cccc}
\hline \% Added & TCP & TCP-5A & TCP-10A \\
\hline$\alpha-\mathrm{TCP}^{*}$ & 100 & 95 & 90 \\
$\mathrm{C}_{3} \mathrm{~S}$ & -- & 5 & 10 \\
\hline$* 82 \%$ of purity & & &
\end{tabular}

$* 82 \%$ of purity.

Table 2. Selected peaks from $\alpha$-TCP (JCPDS 09-0348) and CDHA (JCPDS 46-0905).

\begin{tabular}{cccc}
\hline Phase & $\mathbf{2 \theta}\left({ }^{\circ}\right)$ & hkl & $\mathbf{I}_{\mathbf{0}}$ \\
\hline$\alpha$-TCP & 30.753 & 170 & 100 \\
CDHA & 31.716 & 211 & 100 \\
\hline
\end{tabular}

a time/step ratio of $1 \mathrm{~s}$ in the $2 \theta$ range $30-34^{\circ}$. In order to obtain the in situ measurements, different cement samples were previously prepared in several holder samples and placed under the XRD beam at desired time.

The crystallite size $(\tau)$ in the perpendicular direction to more intense reflections of $\alpha$-TCP and CDHA (Table 2) was determined by the Debye-Scherrer equation (Equation 1 ). In this case, $\beta$ is the line broadening due to the effect of small crystallites (in radians) calculated according to the Bartram method ${ }^{17} ; \mathrm{K}$ is the shape factor, which usually takes a value of about $0.9^{18} ; \lambda$ is $1,54182 \AA$ and $\theta$ is the diffraction peak's angle.

$\tau=\frac{K \lambda}{\beta \cos \theta}$

Morphological differences within 24h were characterized by Scanning Electron Microscopy (SEM) using a JEOL microscope (JSM-6060) on gold-coated samples.

\section{Results and Discussion}

Figures 1-3 show the XRD patterns of in situ observation of the phase evolution of calcium phosphate cements in the first $72 \mathrm{~h}$ of hydration. For traditional TCP cements (Figure 1), peaks of $\alpha$-TCP (JCPDS 29-0359) were mainly observed during different times and only around $72 \mathrm{~h}$ of hydrolysis the incipient formation of amorphous CDHA (JCPDS 46-0905) was detected. In addition, the characteristic peaks of $\beta$-TCP (JCPDS 09-0169), which are not involved in the hydration process, were also found.

After the addition of $\mathrm{C}_{3} \mathrm{~S}$ (Figure 2), the diffraction peaks of CHDA appeared at lower times of hydrolysis (24h) and seemed to be more crystalline than those formed by TCP specimens. Gradual sharpness of the peaks, indicating the growth and increase of crystallite size, were observed. Unreacted peaks of $\alpha$-TCP and $\beta$-TCP were also noted. Larger concentrations of $\mathrm{C}_{3} \mathrm{~S}$ (Figure 3 ) produced a delay in the formation of CDHA when compared with minor

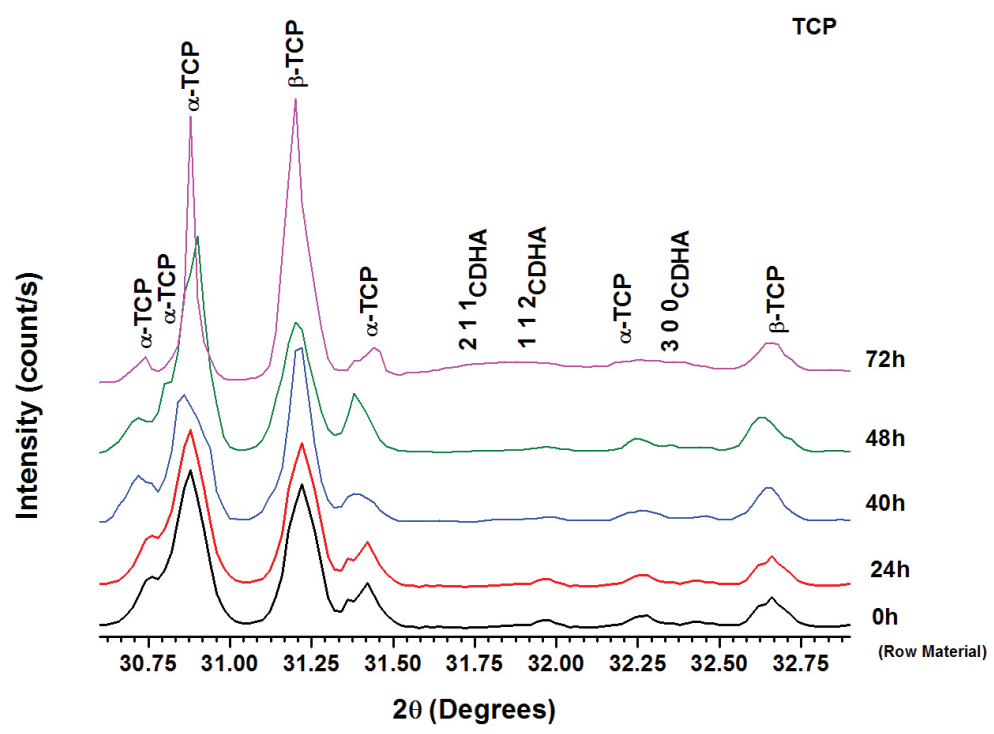

Figure 1. XRD patterns of TCP under in-situ setting condition within 72 hours. 


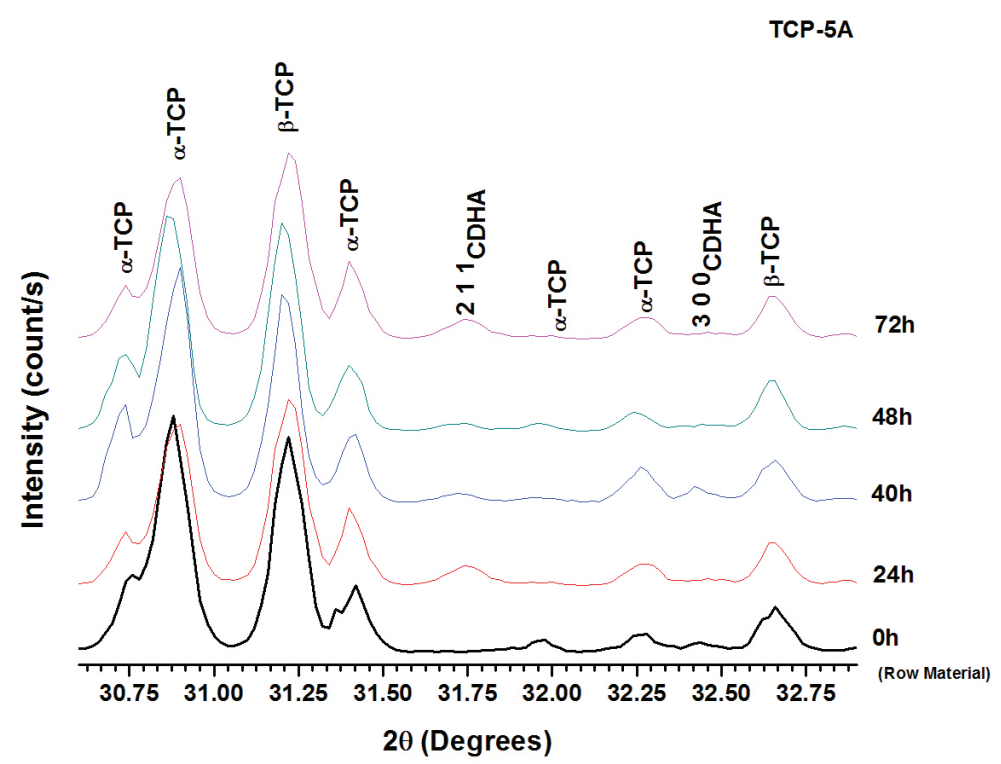

Figure 2. XRD patterns of TCP-5A under in-situ setting condition within 72 hours.

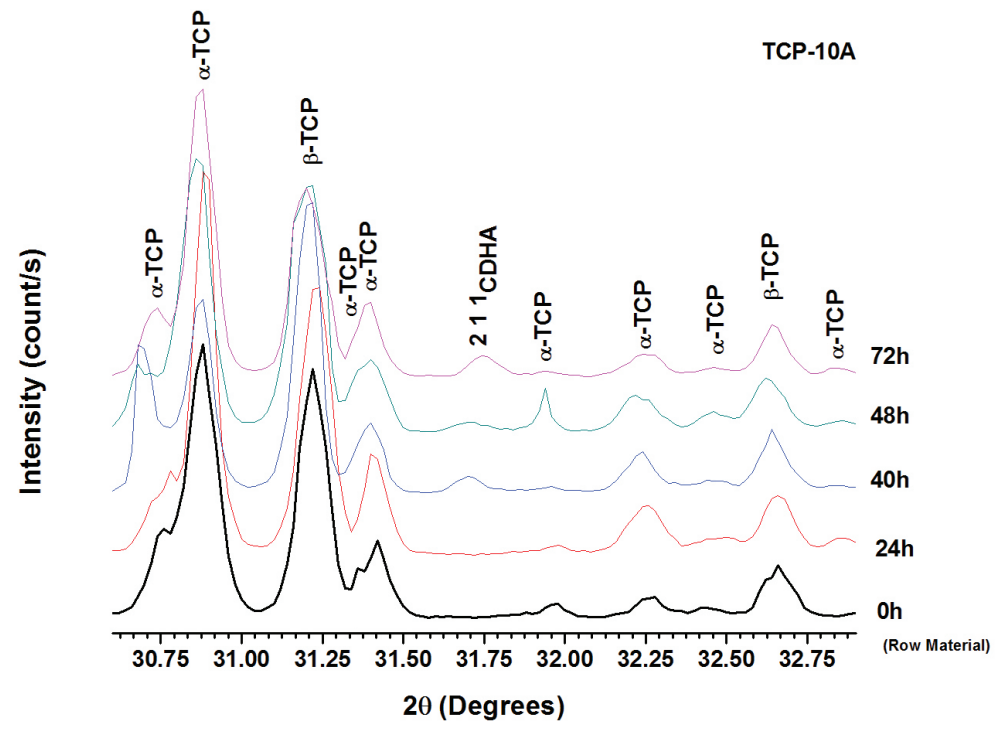

Figure 3. XRD patterns of TCP-10A under in-situ setting condition within 72 hours.

additions; however, the formation of the apatite takes place earlier than in case of TCP samples (40h of hydrolysis).

For TCP-5A and TCP-10A a shift to higher angles for the 211 lattice planes was observed after $72 \mathrm{~h}$ indicating the possibility of the incorporation of some silicon ions into the CDHA structure maybe by the formation of $\mathrm{Ca}_{10}\left(\mathrm{PO}_{4}\right)_{6-\mathrm{x}}\left(\mathrm{SiO}_{4}\right)_{\mathrm{x}} \mathrm{OH}_{1-\mathrm{x}}{ }^{19}$.

For all samples, preferred orientation for some lattice planes for $\alpha$-TCP was found i.e. TCP-10 (40h) hkl 113, TCPA-10A (48h) hkl 530. Since an ideal polycrystalline sample consists of crystals or crystal fragments completely oriented at random, and in real samples of euhedral crystals the preferred orientation of particles is always present; the measured intensities could vary even when the phase content remains the same.
The results of the calculation of the mean crystallite size are shown in Table 3 . As it should be expected, $\alpha$-TCP crystals are decreasing their size when dissolved, while hydroxyapatite crystals grow as the precipitation occurs over time. Notice that in the case of TCP-5A sample it is possible to detect small crystals after 24 hours of hydrolysis and the crystals precipitated during setting of $\mathrm{TCP} / \mathrm{C}_{3} \mathrm{~S}$ are smaller than those obtained by the traditional cement. In addition, the increase in the amount of silicate added is inversely proportional to the size of precipitated crystals.

The addition of $\mathrm{C}_{3} \mathrm{~S}$ to $\alpha$-TCP-based cements produces a delay in the dissolution of $\alpha$-TCP grains and precipitation of CDHA due to: i) the formation of $\mathrm{Ca}(\mathrm{OH})_{2}$, which results in alkaline conditions during $\mathrm{Ca}_{3} \mathrm{SiO}_{5}$ hydrolysis; and ii) the formation of a dense calcium silicate hydrate gel (C-S-H) 
Table 3. Crystallite size $(\tau)$ of $\alpha$-TCP and CDHA particles during hydrolysis.

\begin{tabular}{lcccccccc}
\hline \multirow{2}{*}{$\begin{array}{c}\text { Crystallite Size } \\
(\mathbf{n m})\end{array}$} & \multicolumn{4}{c}{$\boldsymbol{\alpha}$-TCP } & \multicolumn{3}{c}{ CDHA } \\
\cline { 2 - 10 } & $\mathbf{2 4 h}$ & $\mathbf{4 0 h}$ & $\mathbf{4 8 h}$ & $\mathbf{7 2 h}$ & $\mathbf{2 4 h}$ & $\mathbf{4 0 h}$ & $\mathbf{4 8 h}$ & $\mathbf{7 2 h}$ \\
\hline TCP & 235.21 & 106.24 & 50.28 & 28.34 & -- & -- & -- & 64.35 \\
TCP-5A & 117.72 & 71.07 & 58.56 & 31.63 & 25.25 & 58.59 & 71.07 & 90.04 \\
TCP-10A & 166.35 & 105.73 & 56.66 & 28.64 & -- & 17.58 & 19.09 & 38.59 \\
\hline
\end{tabular}

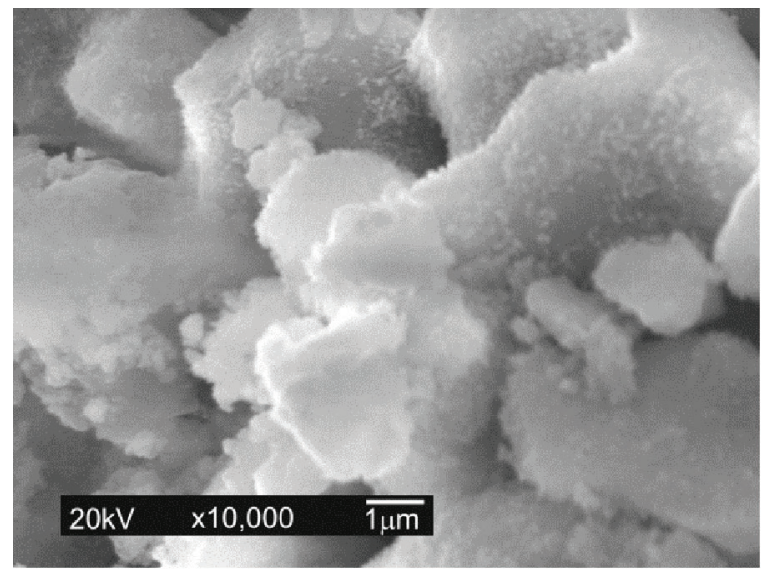

(a)

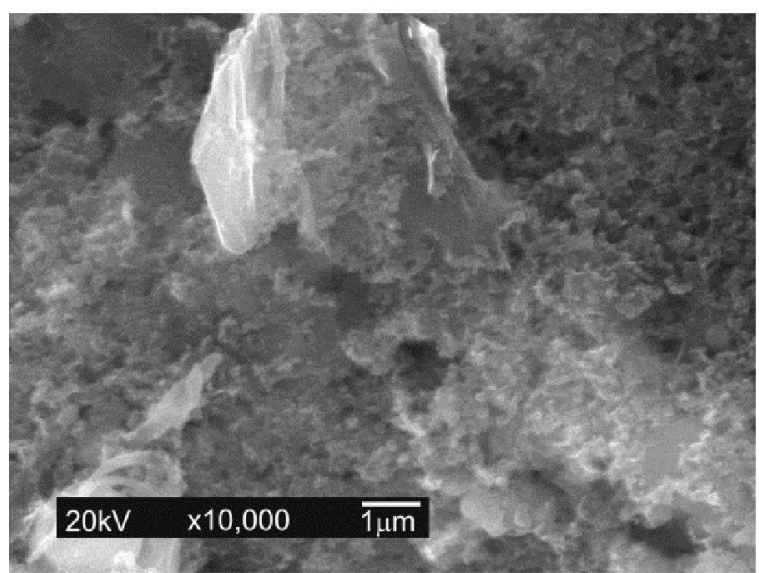

(a)

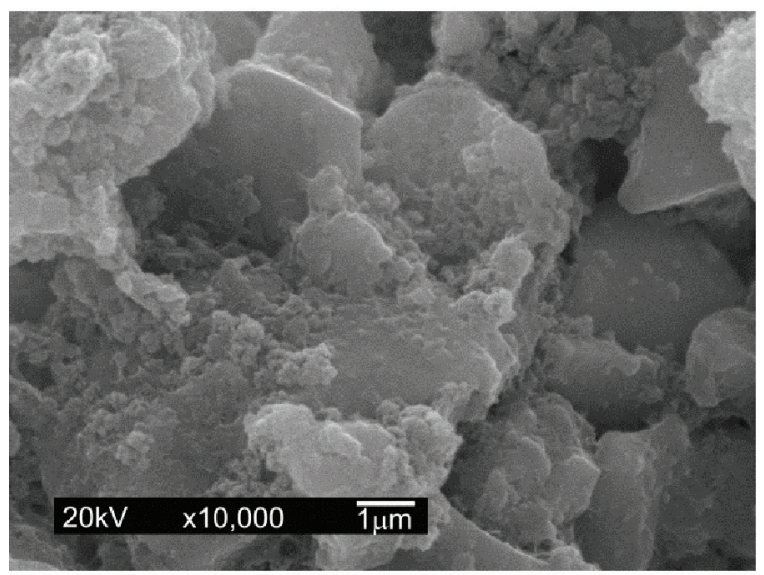

(a)

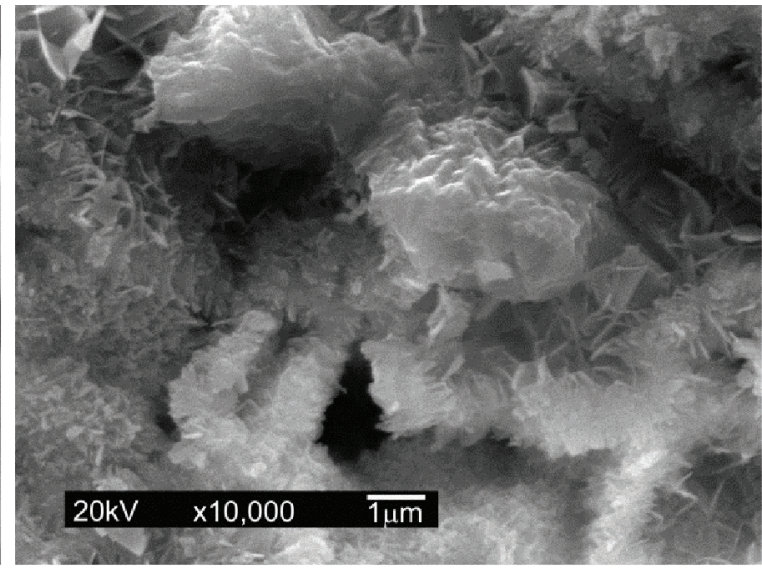

(b)

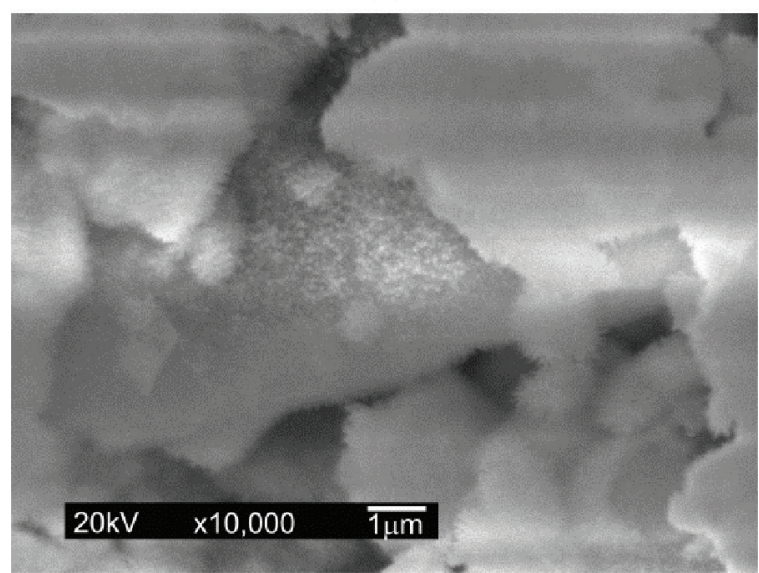

(b)

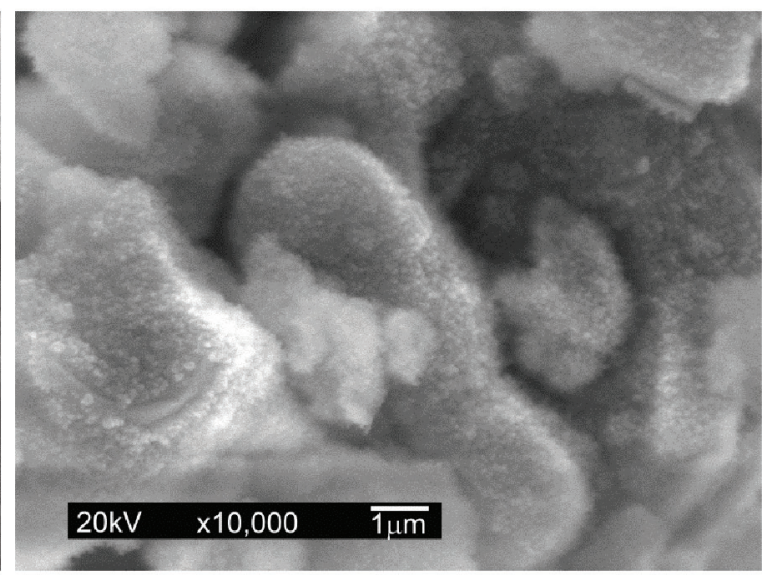

(b)

Figure 4. SEM micrographs of surface (a) and fracture surface (bulk) (b) at $24 \mathrm{~h}$ of $\alpha$-TCP, TCP-5A, and TCP-10A. 
on the surface of $\alpha$-TCP particles (Figure 4); the presence of silicon ions on the new formulations promotes apatite nucleation at early hydration as demonstrated by other authors $^{20,21}$.

Even when setting times were higher than expected and the mechanical properties of the composites were not improved in the first $24 \mathrm{~h}$ as revealed in earlier studies ${ }^{11}$, the presence of $\mathrm{C}_{3} \mathrm{~S}$ induces early precipitation of CDHA at nanoscale thus it improves the biocompatibility of the formulations. By calculating the crystallite sizes it is possible to justify that a significant improvement in the mechanical properties at early stages is not possible since the crystal growth is the responsible for the adherence and interlocking of the crystalline grains, which results in hardening and mechanical resistance.

The results of the microstructural analyses within $24 \mathrm{~h}$ of hydrolysis are displayed in Figure 4. For $\alpha$-TCP-based cement, a fine layer of CDHA crystals was observed on the surface of $\alpha$-TCP grains, while the fracture surface showed typical petal-like plates of CDHA and the presence of some hollows-shells ${ }^{22}$. After adding $\mathrm{C}_{3} \mathrm{~S}$, it was observed the formation of a gelatinous coating of calcium silicate hydrate (C-S-H) on the surface of the $\alpha$-TCP grains which did not react in the early stages of hydration. Neither petal-like plates nor needle-like crystals of hydroxyapatite, distinctive of the beginning of setting and hardening of the CPC, were found at the surface of samples. However, in the inner, it was possible to see the deposition of small CDHA crystals on the top of the larger $\alpha$-TCP particles.

With larger additions of $\mathrm{C}_{3} \mathrm{~S}$, some typical hexagonal habits of $\mathrm{Ca}(\mathrm{OH})_{2}$-which grows into a void where space restrictions are minimal- appeared on the surface allowing development of euhedral forms, while a fibrillar and amorphous type I C-S-H morphology was observed at the fracture surface.

The differences found between DRX and SEM can be attributed to the inhomogeneity of the samples that could produce variable results depending to the studied area, and to the inherent limitations of the X-ray technique that does

\section{References}

1. Dorozhkin SV. Medical application of calcium orthophosphate bioceramics. BIO. 2011; 1(1):1-51. http://dx.doi.org/10.5618/ bio.2011.v1.n1.1.

2. Ginebra MP. Calcium phosphate bone cements. In: Deb S, editor. Orthopaedic bone cements. Boca Raton: CRC; 2008. p. 206-230. Chapter 10

3. Vallet RM. Bio-ceramics with clinical applications. London: John Wiley \& Sons; 2014.

4. Dorozhkin SV. Self-setting calcium orthophosphate formulations: cements, concretes, pastes and putties. International Journal of Material Chemistry. 2011; 1(1):1-48. http://dx.doi.org/10.5923/j.ijmc.20110101.01.

5. Zhai W, Lu H, Chen L, Lin X, Huang Y, Dai K, et al. Silicate bioceramics induce angiogenesis during bone regeneration. Acta Biomaterialia. 2012; 8(1):341-349. http://dx.doi. org/10.1016/j.actbio.2011.09.008. PMid:21964215 not permit the detection of the C-S-H gel at early stages of reaction.

Usually, traditional XRD does not allows a real time determination of the phases but enables us to determine the phases present in the sample without differentiating between the surface and the bulk. When comparing the obtained results with those acquired from traditional XRD some differences become apparent ${ }^{11}$. While former results show that the transformation $\alpha-\mathrm{TCP} / \mathrm{CDHA}$ does not takes place in the first $24 \mathrm{~h}$ for the studied formulations and the SEM results were inconclusive, the in situ study of the surface of materials by high-energy XRD shows that the addition of $\mathrm{C}_{3} \mathrm{~S}$ induces early precipitation of nano crystals of hydroxyapatite at this setting time.

The cellular response to an implant or a biomaterial is associated with its morphologic, chemical, and electrical surface characteristics ${ }^{23}$. Since the hydrolysis of both, the $\alpha$-TCP and the $\mathrm{C}_{3} \mathrm{~S}$, is highly dependent on diffusion of the liquid through the material, a higher degree of transformation of the bulk related to the surface is often observed.

\section{Conclusions}

The in situ hydrolysis of $\alpha-\mathrm{TCP} / \mathrm{C}_{3} \mathrm{~S}$ bone cement at early stages was studied under high energy $\mathrm{X}$-ray diffraction using a synchrotron source. The presence of $\mathrm{C}_{3} \mathrm{~S}$ induces apatite precipitation at nanoscale within the first $24 \mathrm{~h}$ as indicated by the calculation of crystallite size. The in situ study using this technique allows us to arrive at more accurate results than those obtained through the conventional XRD method in relation to the role of silicon in the dissolution and hydrolysis of $\alpha$-TCP-based cements.

\section{Acknowledgements}

The authors acknowledge the financial support from CAPES, the Brazilian Government entity dedicated to the training of human resource and also thank the Brazilian Synchrotron Light Laboratory (LNLS), Project: D10AXRD2-9284.

6. Camiré CL, Saint-Jean SJ, Mochales C, Nevsten P, Wang JS, Lidgren $\mathrm{L}$, et al. Material characterization and in vivo behavior of silicon substituted $\alpha$-tricalcium phosphate cement. Journal Biomedical Material Research Part B, Applied Biomaterials. 2006; 76(2):424-431. http://dx.doi.org/10.1002/jbm.b.30385. PMid:16184531

7. Wu $\mathrm{C}$ and Chang J. A review of bioactive silicate ceramics. Biomedical Materials. 2013; 8(3):032001. http://dx.doi. org/10.1088/1748-6041/8/3/032001. PMid:23567351

8. Correa D, Almirall A, Carrodeguas RG, Santos LA, De Aza AH, Parra J, et al. $\alpha$-Tricalcium phosphate cements modified with b-dicalcium silicate and tricalcium aluminate: physicochemical characterization, in vitro bioactivity and cytotoxicity. Journal of Biomedical Materials Research Part B: Applied Biomaterials. 2015; 103(1), 72-83. http://dx.doi.org/10.1002/jbm.b.33176.

9. Watanabe M, Tanaka M, Sakurai M and Maeda M. Development of calcium phosphate cement. Journal of the European Ceramic Society. 2006; 26(4-5):549-552. http:// dx.doi.org/10.1016/j.jeurceramsoc.2005.07.003. 
10. Cárdenas L, Takeuchi A, Matsuya S and Ishikawa K. Effect of tricalcium silicate addition on basic properties of $\alpha$-tricalcium phosphate cement. Journal of the Ceramic Society of Japan. 2008; 116(1349):83-87. http://dx.doi.org/10.2109/ jcersj2.116.83.

11. Morejón-Alonso L, Ferreira OJ, Carrodeguas RG and dos Santos LA. Bioactive composite bone cement based on $\alpha$-tricalcium phosphate/tricalcium silicate. Journal of Biomedical Materials Research Part B: Applied Biomaterials. 2012; 100B(1):94-102. http://dx.doi.org/10.1002/jbm.b.31926. PMid:22006674

12. Morejón-Alonso L, Carrodeguas RG and Santos LA. Effects of silica addition on the chemical and mechanical properties of a new $\alpha$-tricalcium phosphate/tricalcium silicate cement. Materials Research. 2011; 14(4):475-482. http://dx.doi. org/10.1590/S1516-14392011005000072.

13. Ginebra MP, Fernández E, Driessens FCM and Planell JA. Modeling of the hydrolysis of $\alpha$-tricalcium phosphate. Journal of the American Ceramic Society. 1999; 82(10):2808-2812. http://dx.doi.org/10.1111/j.1151-2916.1999.tb02160.x.

14. Hsu H-C, Tuan W-H and Lee H-Y. In-situ observation on the transformation of calcium phosphate cement into hydroxyapatite. Materials Science and Engineering C. 2009; 29(3):950-954. http://dx.doi.org/10.1016/j.msec.2008.08.014.

15. Morejón-Alonso L, Ferrari MB, Camassola M, Carrodeguas $\mathrm{R}$ and Santos LA. In vitro citotoxicity of calcium phosphatesilicate composite bone cement. In: 6th Latinoamerican Congress of Biomaterials and Artificial Organs; 2010; Gramado, RS. 2010; p. 1-10.
16. Morejón-Alonso L. Avaliação de cimentos ósseos de Fosfatos de Cálcio com adições de Aluminato e Silicato de Cálcio. [Tese]. Porto Alegre: Universidade Federal do Rio Grande do Sul; 2011.

17. Bartram SF. Handbook of X Rays. New York: McGraw-Hill Book; 1967. 17:1-6.

18. Bermúdez-Polonio J. Métodos de difracción de rayos $X$ : principios y aplicaciones. Madrid: Pirámide; 1981.

19. Pietak AM, Reid JW, Stott MJ and Sayer M. Silicon substitution in the calcium phosphate bioceramics. Biomaterials. 2007; 28(28):4023-4032. http://dx.doi.org/10.1016/j. biomaterials.2007.05.003. PMid:17544500

20. Kim K, Patel M and Fisher J. Nanomaterials for musculoskeletal tissue engineering. In: Sitharaman B, editor. Nanomaterials handbook. Boca Raton: CRC Press; 2011.

21. Mabrouk M, Selim MM, Beherei H and El-Gohary MI. Effect of incorporation of nano bioactive silica into commercial Glass Ionomer Cement (GIC). Journal of Genetic Engineering Biotechnology. 2012; 10(1):113-119. http://dx.doi. org/10.1016/j.jgeb.2012.01.001.

22. Hadley DH, Dolch WL and Diamond S. On the occurrence of hollowshell hydration grains in hydrated cement paste. Cement and Concrete Research. 2000; 30(1):1-6. http://dx.doi. org/10.1016/S0008-8846(99)00207-0.

23. Chesmel KD and Black J. Cellular responses to chemical and morphologic aspects of biomaterial surfaces. I. A novel in vitro model system. Journal of Biomedical Materials Research. 1995; 29(9):1089-1099. http://dx.doi.org/10.1002/ jbm.820290909. PMid:8567707 